\title{
A EXIGÊNCIA DO EXAURIMENTO DA JUSTIÇA DESPORTIVA: INCONSTITUCIONALIDADE OU MITIGAÇÃO DO PRÍNCÍPIO DA INAFASTABILIDADE DA JURISDIÇÃO?
}

\author{
Edson Lemos ${ }^{1}$ \\ Rafael Maas dos Anjos ${ }^{2}$
}

\section{RESUMO}

A exigência do exaurimento da justiça desportiva configura afronta ao princípio da inafastabilidade da jurisdição? A resposta a esse questionamento é o foco do presente estudo. No meio jurídico, desde há muito, verifica-se o ajuizamento de demandas judiciais que possuem por objeto conflitos na seara da justiça desportiva. Para o conhecimento do conflito na via judicial e o recebimento de eventual ação, é necessário passar pelo exame de uma questão preliminar: verificar se o litígio já se esgotou na seara desportiva ou se restou superado o prazo legal para seu exame. Nesse contexto, conforme se verá, a exigência do esgotamento de determinada quaestio na justiça desportiva configura a mitigação do princípio da inafastabilidade da jurisdição, e não a sua inconstitucionalidade. Buscar-se-á mapear os fundamentos constitucionais respectivos, dando-se destaque para o direito desportivo, além de analisar o direito de ação, sua origem, importância e relação com o princípio do acesso à justiça. Discorrer-se-á acerca do contencioso desportivo, a fim de encontrar subsídios capazes de esclarecer que a disposição do art. $217, \S 1^{\circ}$, da Constituição Federal não fere o comando contido no art. $5^{\circ}, \mathrm{XXXV}$, também da Carta Magna, podendo ambos os dispositivos constitucionais conviverem em harmonia.

Palavras-chave: Acesso à justiça. Inafastabilidade da jurisdição. Poder Judiciário. Justiça desportiva.

\footnotetext{
${ }^{1}$ Mestre em Ciência Jurídica pela Universidade do Vale do Itajaí (UNIVALI), 2014. Especialista em Gestão e Modernização do Poder Judiciário pela UNISUL, convênio TJSC, 2008. Especialista em Direito Público pela UNISUL, 2017. Assessor de Gabinete. E-mail: edson.lemos@tjsc.jus.br

${ }^{2}$ Doutorando em Ciência Jurídica pela Universidade do Vale do Itajaí (2017), em convênio de Dupla Titulação com a Universidade de Alicante, Espanha. Mestre em Ciência Jurídica pela Universidade do Vale do Itajaí (UNIVALI) (2015), com dupla titulação pela Universidade de Alicante, Espanha. Pós-graduado, em nível de Especialização, em Direito e Gestão Judiciária pela Academia Judicial do Tribunal de Justiça de Santa Catarina (2010). Pós-graduado, em nível de Especialização, em Direito Material e Processual Civil pelo Complexo de Ensino Superior de Santa Catarina (CESUSC), em convênio com a Escola Superior da Magistratura do Estado de Santa Catarina (ESMESC) (2010). Juiz de Direito. E-mail: anjos@ @jsc.jus.br
} 


\section{INTRODUÇÃO}

O exercício da justiça desportiva impõe o exame dos conflitos relacionados ao direito desportivo. Tal análise prévia por órgão especializado é exigência constitucional para eventual exame pelo Poder Judiciário, conforme disposição do art. $217, \S 1^{\circ}$, da Constituição Federal. Trata-se de um procedimento peculiar do ordenamento jurídico brasileiro, sendo condição da ação - pressuposto - na justiça estatal o esgotamento da discussão na esfera administrativa - justiça desportiva.

Por outro lado, o livre acesso à justiça é também mandamento constitucional - art. $5^{\circ}$, inc. XXXV, da Constituição Federal -, e a inafastabilidade da jurisdição, muitas vezes, é utilizada como argumento capaz de afastar a referida regra do $\S 1^{\circ}$ do art. 217 da Carta Magna.

A condição peculiar de exigir-se o exaurimento do embate na justiça desportiva é tema, portanto, que merece atenção pela sua importância para a sociedade brasileira, que tem no desporto um fenômeno sociocultural de grande impacto e influência, seja no aspecto do entretenimento e lazer, seja por seu poderio econômico.

Pretende-se, nestas breves linhas, discutir a respeito do conflito entre as normas constitucionais destacadas, apontando se há eventual antinomia entre dispositivos constitucionais ou se ambos podem conviver harmonicamente.

Para tanto, o presente estudo utilizar-se-á do método dedutivo na fase de investigação, por meio da técnica de pesquisa bibliográfica ${ }^{3}$.

\section{DA INAFASTABILIDADE DA JURISDIÇÃO E O LIVRE ACESSO À JUSTIÇA}

O princípio da inafastabilidade da jurisdição ou do livre acesso à justiça, que se transmuda no fundamental direito de ação, teve inserção primordial na Constituição

\footnotetext{
3 PASOLD, Cesar Luiz. Metodologia da pesquisa jurídica: teoria e prática. 12 ed. São Paulo: Conceito Editorial, 2011, p. 205-210. "Método dedutivo: base lógica da dinâmica da Pesquisa Científica que consiste em pesquisar e identificar as partes de um fenômeno e colecioná-las de modo a ter uma percepção ou conclusão geral [...]. Técnica: conjunto diferenciado de informações, reunidas e acionadas em forma instrumental, para realizar operações intelectuais ou físicas, sob o comando de uma ou mais bases lógicas de pesquisa".
} 


\section{Ranctab

Brasileira de 1946, cuja redação assim dispunha: “Art. 141, § $4^{\circ}$ - A lei não poderá excluir da apreciação do Poder Judiciário qualquer lesão de direito individual".

Tal disposição foi repetida posteriormente nas Cartas Magnas de 1967 e 1969 (Emenda Constitucional n. 01/69), as quais conservaram a redação daquele artigo; porém, elas impuseram exceções que eram fruto do conturbado momento histórico-político da época - ditadura militar.

Foi no final da década de 1960 e nos anos que se seguiram que o Brasil viveu dias de limitações a direitos que até então já estavam consolidados e consagrados. Uma dessas flagrantes limitações se deu com a vedação ao direito de ação e, por conseguinte, com supressão ao princípio da inafastabilidade da jurisdição quando estabelecidas condições tais como a obrigatoriedade de exaurimento prévio nas vias administrativas (BOGDAN, 2009, p. 22).

Contudo, os anos de ditadura passaram e, como resultado de uma construção democrática, a Constituição Federal de 1988 trouxe, entre outros direitos e garantias fundamentais, a disposição do inc. XXXV do art. $5^{\circ}$, ampliando o direito de acesso à justiça ao preconizar que "a lei não excluirá da apreciação do Poder Judiciário lesão ou ameaça a direito".

Trata-se de importante garantia constitucional e direito fundamental do estado democrático de direito, conforme assevera Didier, in verbis:

O direito fundamental (situação jurídica, portanto) composto por um conjunto de situações jurídicas, que garantem ao seu titular o poder de acessar os tribunais e exigir deles uma tutela jurisdicional adequada, tempestiva e efetiva. É direito fundamental que resulta da incidência de diversas normas constitucionais, como os princípios da inafastabilidade da jurisdição e do devido processo legal. (2015, p. 366).

A ampliação do acesso à justiça, por meio do direito de ação, deu-se não só para reprimir lesão a direitos (meio repressivo), mas também para permitir medidas preventivas em situações em que direitos estejam ameaçados. A garantia do acesso à justiça, no dizer de Cappelleti e de Garth, passou a ser entendida como meio de efetivação de direitos fundamentais. A respeito: 
O acesso à justiça pode, portanto, ser encarado como o requisito fundamental - o mais básico dos direitos humanos - de um sistema jurídico moderno e igualitário que pretenda garantir, e não apenas proclamar direitos de todos. [...] O "acesso" não é apenas um direito social fundamental, crescentemente reconhecido; ele é também, necessariamente, o ponto central da moderna processualística. (1988, p.12-13).

O direito de ação é instrumento para o acesso à justiça. Pode ser classificado em direito de ação formal e material. O primeiro é garantia constitucional que trata da forma como se pode propor uma ação a fim de resguardar um direito (lida com o "como"); o segundo tutela o próprio direito, efetivado com a concretude do exercício de ação (lida com "o quê"). Marinoni elucida a referida garantia em face do Estado:

Quando se toma em consideração a proibição de o Estado vedar o acesso à jurisdição diante de determinada situação ou de excluir do Poder Judiciário uma afirmação de lesão ou de ameaça a direito, o direito fundamental de ação se porta como uma garantia contra o Estado ou ainda como uma garantia de que o Estado não faça algo para impedir o exercício do direito de ação e o acesso à justiça. Acontece que o direito fundamental de ação, assim como acontece com os direitos fundamentais no Estado constitucional, exige prestações estatais positivas voltadas a sua plena realização concreta. Melhor dizendo: o direito fundamental de ação não obriga o Estado a protegê-lo nas relações privadas (como ocorreria se fosse um direito fundamental material de proteção) ou é uma mera garantia do cidadão à tutela jurisdicional estatal. $\mathrm{O}$ direito fundamental de ação obriga o Estado a prestar tutela jurisdicional efetiva a todo e qualquer direito que possa ter sido violado ou ameaçado. Ele não é um direito que exige que o Estado atue para protegê-lo, mas sim um direito que requer que o Estado exerça a função jurisdicional de maneira adequada ou de forma a permitir a proteção efetiva de todos os direitos levados ao seu conhecimento. (MARINONI, 2016, p. 130).

O princípio constitucional da inafastabilidade da jurisdição assegura a todos a possibilidade de acesso ao Judiciário, notadamente quando o jurisdicionado, por algum motivo, não consegue obter espontaneamente a satisfação de seu interesse.

Tal princípio encontra-se garantido também em norma infraconstitucional, mais especificamente, no Código de Processo Civil, art. $3^{\circ}$ - "não se excluirá da apreciação jurisdicional ameaça ou lesão a direito". Esse princípio é amplo e incondicional, não podendo o Judiciário se recusar a examinar e a responder as pretensões que lhe forem direcionadas.

O Estado, na modernidade, tem viabilizado o acesso à justiça por meio de garantias dadas aos cidadãos, para que possam alcançar os seus direitos não apenas 
formalmente, mas efetivamente e concretamente, de forma célere e justa. Isso acontece, inclusive, por intermédio de métodos alternativos de solução de conflitos, que seriam, nas palavras de Spengler (2010, p. 291), possibilidade não jurisdicional de tratamento de disputas, nas quais se atribui legalidade à voz de um conciliador/mediador, que auxilia os conflitantes a compor o litígio. Tais métodos ganharam força na atualidade, porque contribuem para o desafogo de um Poder Judiciário assoberbado e sobrecarregado de demandas e processos.

Constitucionalmente, garante-se pelas vias alternativas que o direito ao efetivo acesso à justiça não fique circunscrito ao mero ajuizamento de uma ação, alcançando efeito muito maior, qual seja, o direito de obtenção da tutela desejada e, por via de consequência, atingindo a pacificação social por meio da solução de um conflito. É por meio da avaliação do resultado alcançado que se mede a efetividade do referido direito fundamental do cidadão de acessar à justiça.

Não obstante o reconhecimento da importância dos métodos alternativos de solução dos conflitos, não se pode negar que o direito constitucional do acesso à justiça prevalece e está intimamente ligado ao direito à tutela jurisdicional do Estado, prestado por meio do Poder Judiciário, que, segundo o artigo $5^{\circ}$, inc. XXXV, da Constituição Federal, possui a missão precípua de apreciar a lesão ou a ameaça a direito - função jurisdicional.

Assim, estabelece-se que o direito de ação em sentido amplo se traduz na garantia e efetivação do princípio constitucional da inafastabilidade da jurisdição ou do livre acesso à justiça. $\mathrm{O}$ direito de ação se conjuga com a garantia do devido processo legal e do contraditório e da ampla defesa.

Por sua vez, o devido processo legal, nas palavras de Didier (2015, p. 67), é um princípio de conteúdo complexo, que tem a função de criar os elementos necessários à promoção do ideal de protetividade dos direitos, integrando o sistema jurídico eventualmente lacunoso.

Gonçalves (2016, p. 65) contribui com a conceituação deste princípio:

O devido processo legal formal (procedural due process) diz respeito à tutela processual. Isto é, ao processo, às garantias que ele deve respeitar e ao regramento legal que deve obedecer. Já o devido processo legal substancial (substantive due process) constitui autolimitação ao poder estatal, que não pode editar normas que ofendam a razoabilidade e afrontem as bases do 


\section{Revista do

regime democrático. Para nós, interessa, sobretudo, o aspecto formal, que diz respeito ao arcabouço processual.

O princípio do contraditório e da ampla defesa encontra disposição no inc. LV do art. $5^{\circ}$ da $\mathrm{CF} / 88$ : "aos litigantes, em processo judicial ou administrativo, e aos acusados em geral são assegurados o contraditório e ampla defesa, com os meios e recursos a ela inerentes". Tal princípio é inerente ao direito de defesa, sendo decorrente da bilateralidade do processo: quando uma das partes alega alguma coisa, há de ser ouvida também a outra, dandose a esta a oportunidade de resposta, seja no âmbito administrativo ou judicial.

Colaborando na construção do conceito do princípio do contraditório, Didier (2015, p. 79) elucida:

O princípio do contraditório é reflexo do princípio democrático na estruturação do processo. Democracia é participação, e a participação no processo opera-se pela efetivação da garantia do contraditório. O princípio do contraditório deve ser visto como exigência para o exercício democrático de um poder.

$[\ldots]$

A garantia da participação é a dimensão formal do princípio do contraditório. Trata-se da garantia de ser ouvido, de participar do processo, de ser comunicado, poder falar no processo.

Há porém, ainda, a dimensão substancial do devido princípio do contraditório. Trata-se de poder de influência. Não adianta permitir que a parte simplesmente participe do processo. Apenas isto não é o suficiente para que se efetive o princípio do contraditório. É necessário que se permita que ela seja ouvida, é claro, mas em condições de poder influenciar a decisão do órgão jurisdicional.

Por fim, o mesmo doutrinador disserta acerca do princípio da ampla defesa:

O contraditório e a ampla defesa formam um belo e conhecido par. Não por acaso, estão previstos no mesmo dispositivo constitucional (art. $5^{\circ}, \mathrm{LV}$, $\mathrm{CF} / 1998)$.

Tradicionalmente, a doutrina distinguia ambas as garantias, embora reconhecesse que entre elas havia forte conexão. Bem ilustrativo desta concepção é o entendimento de Delosmar Mendonça Jr.: “... são figuras conexas, sendo que a ampla defesa qualifica o contraditório. Não há contraditório sem defesa. Igualmente é lícito dizer que não há defesa sem contraditório [...] O contraditório é o instrumento de atuação do direito de defesa, ou seja, esta se realiza através do contraditório".

$[\ldots]$ 
A ampla defesa corresponde ao aspecto substancial do princípio do contraditório. (DIDIER, p. 79).

Assim, a inter-relação entre o devido processo legal, o contraditório e a ampla defesa delimita e forma o direito de ação em seu sentido amplo, apresentando-se como garantia necessária para que o Judiciário exerça na plenitude a sua função de dirimir as controvérsias.

Não há dúvidas de que, havendo lesão ou ameaça a direito, surge de imediato o direito de invocar a tutela jurisdicional, não sendo permitida a imposição de nenhuma espécie de condicionamento ao pleno exercício do direito de ação e de restrição ao acesso à justiça.

A consagração do princípio da inafastabilidade da jurisdição possui status de norma constitucional, fomentando a convicção de que não mais se pode admitir a existência de instâncias administrativas de curso forçado. Firmadas essas premissas, a existência de uma disposição constitucional que aparentemente afirma o contrário, ao exigir o exaurimento de uma instância administrativa para o livre acesso à justiça, traz dúvidas e merece especial análise.

A exigência constitucional do art. $217, \S 1^{\circ}$, da $\mathrm{CF} / 88$ é incompatível com o princípio do art. $5^{\circ}$, inc. XXXV, da Carta Magna? Ou trata-se apenas de uma exceção ou mitigação do princípio do acesso à justiça, dadas as peculiaridades do contencioso desportivo?

Para melhor responder a esses questionamentos, necessário se faz contextualizar a discussão com a apresentação do direito desportivo e sua relevância para a ciência do direito e para o viver em sociedade.

\section{DO DIREITO DESPORTIVO}

O desporto é um fenômeno globalizado que integra o cotidiano do homem moderno. Na sociedade brasileira, tal fenômeno sociocultural possui grande importância porquanto não só está plenamente inserido no cotidiano popular, mas também porque retrata traços e características marcantes do povo brasileiro, seja no falar, seja no agir, apresentandose como alternativa para a ascensão social e conquista de efetiva cidadania. 
Vargas e Lamarca (2010, p. 26) discorrem a respeito:

Na sociedade brasileira, em particular nas camadas menos favorecidas (o que não é privilégio destes extratos), o Desporto desponta como um sonho de ascensão à cidadania, como um caminho, às vezes único, para se alcançar, de forma digna, o locus societas e sobreviver à pobreza e à periferia dos direitos fundamentais. Portanto, numa sociedade plural como a brasileira, é "normal" e benéfico, sobretudo pelo seu cunho pedagógico, o delineamento do Direito no universo desportivo.

O esporte se espraia pelos diversos campos de atuação humana, contribuindo e fazendo parte da sua promoção e desenvolvimento. Ezabella enuncia alguns exemplos:

Cultura - Os desportos enriquecem os homens com uma cultura que os acompanha ininterruptamente, tanto que é difícil escrever a história da Grécia sem mencionar os Jogos Olímpicos. [...]

Religião - Nos dias atuais é mais que normal o atleta agradecer a Deus pela vitória, ou então comemorar seu triunfo com as mãos para o céu. [...] $\mathrm{O}$ Papa, que na Itália é conhecido como o "atleta de Deus", por diversas vezes mencionou o futebol em seus discursos, sempre destacando a importância do esporte para a promoção de valores como a tenacidade, o espírito de sacrifício, o respeito mútuo, a lealdade, a amizade e o trabalho em equipe. $[\ldots]$

Política - Em toda a sua história o esporte despertou interesse do poder político. [...] Por outro lado, graças ao uso político que é feito do esporte, ele é utilizado como um meio de se desenvolver novas relações entre os Estados e de promover formas de cooperação internacional. [...]

Economia - O conteúdo econômico do esporte tem estado presente desde suas primeiras manifestações [...]. O ingrediente econômico do esporte moderno passou com o tempo a ser o verdadeiro condicionante do esporte. $[\ldots]$

Sociologia - Os desportos estão contribuindo intensamente para a aproximação dos povos, a integração nacional e a presença internacional. Também contribuem para a mudança de costumes e outras maneiras da vida cotidiana. Seu poder de atração chega a amortecer os antagonismos de povos étnicos e socialmente distintos. (EZABELLA, 2006, p. 22-33).

O desporto representa uma das poucas formas de ascensão social. Não são raros os exemplos de atletas de origem humilde que, ao se consagrar no esporte, alcançam espaço privilegiado na sociedade. Ademais, o esporte produz efeitos positivos no físico e na mente - mens sana in corpore sano -, com o aprimoramento da saúde. No âmbito cultural, promove a integração e a valorização dos costumes; no educacional, promove a inserção de 


\section{Ranctatio

valores como a disciplina, a responsabilidade e a solidariedade; e, no intelectual, desenvolve o raciocínio e a inteligência (ANJOS, 2016, p. 93-94).

Pode-se descrever o desporto como um fenômeno multifacetado, sendo fato social que "desempenha papel considerável de auxiliar o estado na concretização de políticas públicas e governamentais, beneficiando os cidadãos de todas as idades" (ANJOS, 2016, p. 91).

Vale destacar também a influência do desporto no aspecto econômico, pois a sociedade atualmente consome o lazer por meio das práticas esportivas, dando crescimento ao esporte como negócio. Ainda, o desporto contribui para a formação de uma consciência ecológica e para a sustentabilidade - dimensões ambiental, social e econômica -, na "medida em que o desempenho e o rendimento esportivos são diretamente influenciados pelas condições ambientais da região onde se dá a prática desportiva" (ANJOS, 2016, p. 102). A preservação do meio ambiente é fundamental para a formação dos espaços necessários para determinadas práticas desportivas, assim como para as condições ideais de bom desenvolvimento de atividades do esporte.

O desporto é mais do que atividade lúdica e de lazer. Aquilo que no passado era tratado como simples jogo, desde há muito passou a ganhar um ar de seriedade, intensificando-se a competitividade, o que tornou necessária a elaboração de regras e de mecanismos para a exigência de seu cumprimento, a fim de resguardar a disputa justa e a integridade do resultado alcançado. A respeito, José Ricardo Rezende comenta:

Ante as especulações sobre o jogo, podemos concluir que sua formalização, pela renúncia da espontaneidade e sujeição a ordens, retira-lhe dois de seus elementos intrínsecos, que é o divertimento e liberdade (ludicidade), originando um aspecto novo e peculiar, que é a competitividade, fato que acaba por notabilizar o jogo como uma prática esportiva. (REZENDE, 2010, p. 37).

Salienta-se esse elemento da competitividade como fator importante para a transformação do jogo, de uma atividade lúdica, para o que conhecemos por desporto.

Álvaro Melo Filho discorre acerca do desporto: 


\begin{abstract}
O desporto é, sobretudo, é antes de tudo, uma criatura da lei, pois sem o direito, o desporto carece de sentido, porquanto nenhuma atividade humana é mais regulamentada que o desporto. Com efeito, "regras do jogo", "Códigos de Justiça Desportivas", "regulamentos técnicos de competições", "leis de transferências de atletas", "estatutos e regulamentos de entes desportivos", "regulamentação de dopping", atestam que, sem regras e normatização, o desporto torna-se caótico e desordenado, à falta de regras jurídicas para dizer quem ganha e quem perde. (MELO FILHO, 2004, p. 4).
\end{abstract}

Como se vê, existe um universo de normas que envolvem o desporto, permitindo-se falar, muito embora ainda não seja pacífico, no direito desportivo como um ramo autônomo do direito.

Torna-se possível, neste rumo, enxergar no ordenamento jurídico brasileiro uma disciplina legal típica - regime jurídico desportivo -, com princípios e normas congruentes e compatíveis entre si, além de atores e operadores específicos, que devem se submeter a institutos e legislação própria; portanto, tal disciplina merece da ciência do direito um tratamento autônomo (ANJOS, 2016, p. 112).

Alguns doutrinadores, volto a dizer, defendem a autonomia do direito desportivo, pois ele possui um microssistema jurídico, com leis e órgãos próprios. Castro (2002 apud EZABELLA, 2006, p. 45), cita que:

O Direito Desportivo já existe e é efetivamente um novo ramo de Direito e, principalmente, autônomo dos demais. Para os defensores desta corrente, o Direito Desportivo é oriundo da necessidade de regulamentação do desporto além das suas regras básicas de competição. O Direito Desportivo nasceu como qualquer outro ramo do Direito, da necessidade de regulamentação das atividades dos seres humanos, ou seja, são os hábitos e costumes criando legislação, e consequentemente um novo ramo do Direito.

Por sua vez, Melo Filho (1986, p. 19) pensa de forma diversa, apontando uma autonomia híbrida para o direito desportivo, ou seja, "o Direito Desportivo possui, sim, uma autonomia, porém isso não quer dizer que se trate de disciplina isolada com conceito e métodos próprios”.

Na lição de Ezabella (2006, p. 45), extrai-se:

O Direito Desportivo é um ordenamento jurídico diferenciado e autoregulável, além de condensar normas constitucionais, internacionais, 
administrativas, trabalhistas, comerciais, penais, civis e processuais. Tais caracteres específicos denotam não só a complexidade e amplitude da temática jurídico-desportiva, como também suas interfaces com vários ramos do Direito.

Independentemente da corrente a que se filie o estudioso do direito, não se pode negar a presença do direito no mundo esportivo, tampouco do desporto no mundo do direito. Por meio das regras consolidadas na esfera jurídico-desportiva, pode-se garantir organização, proteção e concretização da prática desportiva. E a justiça desportiva tem papel primordial para o enfrentamento dos conflitos advindos das atividades do desporto.

As demandas enfrentadas pela justiça desportiva possuem contornos próprios, sendo temerária a sua aferição diretamente pelos tribunais comuns, seja pelo congestionamento do Poder Judiciário com diversas outras espécies de demanda, seja pelo despreparo deste mesmo Judiciário para as questões jurídico-desportivas, que exigem dos julgadores o conhecimento e a vivência de normas, práticas e técnicas desportivas a que, no dia a dia, não estão afeitos e familiarizados (MELO FILHO, 1995, p. 55). É sobre a justiça desportiva que os olhares neste estudo passam a se voltar.

\section{DA JUSTIÇA DESPORTIVA NO BRASIL}

A justiça desportiva pode ser conceituada como:

O conjunto de instâncias desportivas autônomas e independentes das entidades de administração do desporto dotadas de personalidade jurídica de direito público ou privado, com atribuições de dirimir os conflitos de natureza desportiva e de competência limitada ao processo e julgamento de infrações disciplinares definidas em códigos desportivos. (SCHMITT, 2013, p. 70).

A justiça desportiva não faz parte do Poder Judiciário e, portanto, não há a atuação de juízes togados. Schmitt, em outra obra, compara a justiça desportiva à arbitragem no que se refere a uma outra via para solução de conflitos de interesse:

De um lado, a arbitragem é opcional para as partes, que poderão (i) abdicar do Judiciário e definir a solução de seus conflitos por árbitros privados ou 
(ii) submeter-se à atividade jurisdicional do Estado. De outro, a justiça desportiva é, em regra, pressuposto a ser esgotado antes que a parte mova o Poder Judiciário, composta de forma paritária pelos entes participantes da atividade desportiva. Resguardadas as distinções, arbitragem e justiça desportiva não têm poder para executar diretamente suas decisões, porque a força executiva, o monopólio do exercício da força, permanece inerente ao Estado. (SCHMITT, 2007, p. 63).

De fato, a Constituição Federal de 1988, em seu art. 92, elenca os órgãos pertencentes ao Poder Judiciário: "I - o Supremo Tribunal Federal; I-A o Conselho Nacional de Justiça; II - o Superior Tribunal de Justiça; III - os Tribunais Regionais Federais e Juízes Federais; IV - os Tribunais e Juízes do Trabalho; V - os Tribunais e Juízes Eleitorais; VI - os Tribunais e Juízes Militares; VII - os Tribunais e Juízes dos Estados e do Distrito Federal e Territórios".

Percebe-se que não há a inclusão da justiça desportiva na norma constitucional citada, o que, por si só, é suficiente para afastar o caráter judicial e/ou institucional de seus órgãos. Em verdade, trata-se de uma instância administrativa que se volta para a solução dos conflitos no âmbito das competições e atividades desportivas.

No tocante à natureza jurídica dos órgãos da justiça desportiva, não há um consenso a respeito. Ainda não se faz possível definir com precisão em qual ramo se enquadram as entidades da justiça desportiva: privado, administrativo ou misto. O que é certo, e isto nos basta neste estudo, é o afastamento do caráter jurisdicional próprio do Poder Judiciário.

Schmitt defende que os tribunais de justiça desportiva poderão apresentar natureza jurídica de direito público ou privado.

Terão natureza particular quando vinculados a entidades de administração do desporto (confederações, federações e ligas) e natureza pública quando vinculados a competições promovidas pelo Poder Público (União, Estados e Municípios).

As entidades de administração do desporto, segundo definição da Lei n. 9.615/98, são pessoas jurídicas de direito privado (art. 16), enquanto os tribunais de justiça desportiva constituem unidades autônomas vinculadas a essas entidades de administração (art. 52). A justiça desportiva vinculada às entidades de administração do desporto, portanto, tem natureza privada e deve seguir a estrutura imposta pelos artigos 52 e seguintes da Lei n. 9.615/98. De outro lado, as pessoas jurídicas de direito público interno 
(União, Estados, Distrito Federal e Municípios) podem instituir seus próprios sistemas desportivos e compor seus respectivos tribunais de justiça desportiva. Neste caso, considerando a vinculação com o Poder Executivo, estes órgãos da justiça desportiva serão regidos pelo regime de direito público. (SCHMITT, 2013, p. 76).

Miranda (2007, p. 126), semelhantemente, esclarece que o direito desportivo, por ser um ramo novo, ainda está se adaptando, de modo que a justiça desportiva tem sua atuação ora regulada por normas de natureza privada, ora por normas de ordem pública, possuindo natureza híbrida.

Os órgãos da justiça desportiva estão elencados no art. 52 da Lei n. 9.615/98 (redação dada pela Lei n. 9.981/00), que prevê uma estrutura orgânica de caráter hierárquico, reconhecendo-os como órgãos:

[...] autônomos e independentes das entidades de administração do desporto de cada sistema, compondo-se do Superior Tribunal de Justiça Desportiva, funcionando junto às entidades nacionais de administração do desporto; dos Tribunais de Justiça Desportiva, funcionando junto às entidades regionais da administração do desporto, e das Comissões Disciplinares, com competência para processar e julgar as questões previstas nos Códigos de Justiça Desportiva, sempre assegurados a ampla defesa e o contraditório. (BRASIL, Lei n. 9.615/98).

Como mencionado por Schmitt (2013, p. 78), a autonomia da justiça desportiva está relacionada ao equilíbrio com os demais poderes da entidade de administração desportiva (assembleia e diretoria). Este mecanismo funciona semelhantemente ao sistema de "freios e contrapesos" que vige entre os poderes estatais.

A referida independência da justiça desportiva, prevista no citado art. 52, está vinculada à estrutura dos órgãos judicantes desportivos, bem como à soberania das decisões, protegendo os tribunais de qualquer interferência que possa ocorrer dos atos emanados das entidades diretivas públicas ou privadas.

Noutro viés, a autonomia das entidades desportivas dirigentes e associações, com previsão constitucional (CF/88, art. 217, inc. I) e legal (Lei n. 9.615/98, art. 52), não significa que estas estão autorizadas a descumprir ou desobedecer aos ditames legais. Exemplificando, a garantia de contraditório e ampla defesa deve sempre ser assegurada aos atletas que receberam penalidades em competições, nas mais diversas modalidades 
desportivas.

E já que o assunto é ordenamento jurídico nacional, a justiça desportiva no Brasil submete-se a diversos diplomas normativos: à Constituição Federal, em seu art. 217; aos princípios constitucionais fundamentais do art. $5^{\circ}$ da CF; ao Código de Justiça Desportiva; à Lei n. 9.615/98 (Lei Geral do Desporto ou Lei Pelé); ao Estatuto do Torcedor (Lei n. 10.671/03); sem olvidar-se de todas as demais normas que regulam o desporto, sejam normas complementares, estatutos ou portarias.

Mudando o enfoque, vale neste momento destacar a estrutura dos órgãos da justiça desportiva que funcionam junto às federações, confederações e ligas desportivas. Conforme bem detalhado por Schmitt (2013, p. 98), pode-se estruturar as instâncias e os órgãos da justiça desportiva da seguinte forma: a) Comissão Disciplinar Regional (CDR) e a Comissão Disciplinar Nacional (CDN), que atuam em primeira instância, na forma de colegiados; b) Tribunais de Justiça Desportiva (TJD) de cada estado e modalidade, que atuam em grau recursal e pertencem à mesma jurisdição das federações; c) Superior Tribunal de Justiça Desportiva (STJD) de cada estado e modalidade, que atua na mesma jurisdição das confederações, funcionando como uma terceira instância nas situações de esgotamento da matéria no TJD, ressalvados os casos de foro privilegiado; d) Tribunal Arbitral do Esporte (TAS/CAS), que tem previsão em norma internacional da respectiva modalidade esportiva e é a última instância da justiça desportiva e um órgão judicante internacional, com sede em Lausane (Suíça), utilizando-se da arbitragem e da mediação para a resolução dos conflitos atinentes ao desporto.

Apresentada a estrutura da justiça desportiva e demonstrada a sua vinculação aos diplomas legais que compõem o ordenamento jurídico brasileiro, passa-se a ingressar no tema central do presente artigo, qual seja, a (in)constitucionalidade da disposição do art. 217, $\S 1^{\circ}$, da Constituição Federal - exigência do exaurimento da justiça desportiva para a admissão pelo Poder Judiciário de ações relativas à disciplina e às competições desportivas -,diante do comando contido no art. $5^{\circ}, \mathrm{XXXV}$, também da Carta Magna - a lei não excluirá da apreciação do Poder Judiciário lesão ou ameaça de direito. 


\section{DA EXIGÊNCIA DO EXAURIMENTO DA JUSTIÇA DESPORTIVA COMO UMA MITIGAÇÃO AO PRÍNCÍPIO DA INAFASTABILIDADE DA JURISDIÇÃO}

Passa-se a discorrer sobre o tema central deste breve estudo. Conforme salienta Bogdan (2009, p. 54), analisando-se de forma sistemática, teleológica e gramatical os dois dispositivos constitucionais já indicados $\left(\mathrm{CF} / 88\right.$, art. $5^{\circ}, \mathrm{XXXV}$ - princípio do acesso à justiça ou da inafastabilidade da jurisdição - e art. $217, \S 1^{\circ}$ - exigibilidade prévia das controvérsias desportivas pela justiça desportiva), vislumbra-se um aparente conflito entre as normas. A suposta colisão residiria na eventual impossibilidade de fixar condições para que o Poder Judiciário possa analisar lesão ou ameaça de direito; no caso, exigir o prévio esgotamento das instâncias desportivas para a análise, pelo poder judiciário, do contencioso desportivo.

A doutrina e a jurisprudência majoritária têm se inclinado a reconhecer que há uma convivência harmônica entre as normas elencadas; ou seja, o comando normativo contido no art. $217, \S 1^{\circ}$, da CF/88 não feriria o princípio do acesso à justiça - inc. XXXV do art. $5^{\circ}$ da $\mathrm{CF} / 88$-, pois na verdade se trata de uma mitigação, relativização ou limitação de tal regra constitucional.

A questão não é remansosa. Manoel Gonçalves Ferreira Filho, citado por Felipe Branco Bogdan, entende que "na verdade, esta norma importaria uma exceção ao disposto no art. $5^{\circ}, \mathrm{XXXV}$. É uma exceção escandalosa. Já que não é prevista quanto a outras modalidades de contencioso administrativo que se conhecem no País" (BOGDAN, 2009, p. $55)$.

Contudo, data venia, tal entendimento merece ressalvas, conforme se expõe. Primeiramente, por se tratar de exceção imposta pela própria Constituição Federal, não há que se falar em inconstitucionalidade da disposição do art. 217, § $1^{\circ}$, da Carta Magna. Ora, se a norma fosse infraconstitucional, poder-se-ia cogitar da alegada inconstitucionalidade. Mas a opção pelo referido dispositivo constitucional foi do próprio legislador constituinte, detentor do poder constituinte originário, que alçou tal condição a comando constitucional.

José Joaquim Gomes Canotilho, tratando do princípio da unidade da constituição, ensina que a Carta Magna deve ser interpretada de modo a evitar contradições, 


\section{Rachato

antinomias e antagonismos entre suas normas. As colisões devem ser evitadas. Como consequência, o intérprete deve considerar a Constituição em sua totalidade, buscando o seu cerne e promovendo uma interpretação disciplinada na vontade objetiva do legislador originário, ou seja, observando a plenitude lógica, respeitando a unidade codificatória e, por fim, esforçando-se no sentido de harmonizar e equalizar os pontos de tensão existentes dentro da lei máxima do ordenamento jurídico pátrio (CANOTILHO, 1991, p. 1207).

Percebe-se, no tema em foco, que o interesse do legislador constituinte não foi afastar do Poder Judiciário a apreciação das controvérsias relativas ao desporto, mas tão somente dar celeridade ao contencioso desportivo e evitar a burocratização imposta pelo processo judicial.

Álvaro de Melo Filho compactua do entendimento de que a exceção prevista constitucionalmente não deve ser interpretada como exclusão do Poder Judiciário das questões desportivas, mas sim como a imposição de uma condição para a maior especialidade e celeridade no julgamento do contencioso relacionado às competições e à disciplina desportiva (MELO FILHO, 2011, p. 238). Referido autor disciplina que:

De toda sorte, este recurso ao Poder Judiciário não pode, na concepção de muitos autores, viabilizar uma re(discussão) do conteúdo ou do mérito desportivo envolvendo os campos da disciplina e competição desportivas, após decisão da Justiça Desportiva, cujos membros estão melhor preparados para conhecer e apreciar as demandas desportivas sujeitas a normas tão distintas e peculiares.

[...]

E não é diverso o posicionamento de Rodolfo Mancuso de Camargo ao assinalar o entendimento de que ao Judiciário, nestas situações, compete apenas a análise da observância ou não das formalidades legais.

[...]

Sendo assim, entende que as decisões por ela proferidas são, em verdade, atos administrativos discricionários e, portanto, insusceptíveis de controle jurisdicional no tocante ao mérito. (MELO FILHO, 2011, p. 241).

Veja-se que a decisão na justiça desportiva pode ser objeto de ação no Poder Judiciário quando violar questões processuais ou ferir a estrita legalidade; noutro viés, não devem ser revistos os aspectos de ordem administrativa, respeitando-se o mérito administrativo. 
Repisa-se: não há no texto legal impedimento para a busca da proteção jurisdicional do Poder Judiciário; o que existe, de fato, é uma relativização ou mitigação deste princípio, exigindo-se, por primeiro, o esgotamento das instâncias da justiça desportiva, para somente então, por meio de uma via secundária e caso seja da vontade e da necessidade do perseguidor do direito, buscar-se a justiça comum.

Indo além, a referida mitigação ou exceção constitucional ao livre acesso à justiça, quando o assunto é o contencioso desportivo, possui outra ressalva. Apesar de se reconhecer a competência da justiça desportiva como órgão decisório inicial das demandas de ordem desportiva, a Carta Magna conferiu um prazo máximo para que tais decisões sejam proferidas no âmbito administrativo, sob pena de transmitir tal competência ao Poder Judiciário. Tal previsão normativa encontra-se no $\S 2^{\circ}$ do mesmo art. 217 , o qual determina que a justiça desportiva terá o prazo máximo de 60 dias, contados da instauração do processo, para proferir a decisão final.

Veja-se, portanto, que o Poder Judiciário poderá, de duas formas, apreciar eventual questão relativa à disciplina e às competições desportivas: quando exaurida a discussão na referida instância administrativa ou quando esse órgão de julgamento não proferir decisão no prazo de 60 dias, a contar da data da instauração do processo.

Tais hipóteses demonstram a compatibilidade existente entre o princípio do acesso à justiça ou da inafastabilidade da jurisdição e a nomeação, no âmbito constitucional, da justiça desportiva como instância inicial para resolução das demandas de ordem estritamente desportiva. Não há que se falar, portanto, em colisão ou antinomia de normas constitucionais, mas sim de uma limitação entre os preceitos legais em questão, cuja adequação lógica respeita a legislação e as peculiaridades das matérias afetas à justiça desportiva, que possuem características próprias, com regramento específico e de celeridade acentuada.

Por oportuno, esclarece-se que, da leitura do art. 52, § 2º da Lei n. 9.615/98, vislumbra-se a determinação de que “o 'recurso' ao Poder Judiciário não prejudicará os efeitos desportivos validamente produzidos em consequência da decisão proferida pelos tribunais da justiça desportiva". Ora, o vocábulo "recurso", importante esclarecer, foi empregado como sinônimo de ingresso de ação no Poder Judiciário, dentro das situações 
elencadas nos $\S \S 1^{\circ}$ e $2^{\circ}$ do art. 217 da $\mathrm{CF} / 88$, não devendo ser considerada a justiça estatal como uma instância superior à justiça desportiva, porquanto de naturezas distintas.

Finalizando, uma última ponderação. Considera-se esgotada a instância judicial desportiva, conforme descreve Bogdan (2009, p. 57), “quando, efetivamente, a parte transpuser todas as instâncias, fazendo uso de todos os recursos cabíveis".

Concluindo, o comando normativo de exigibilidade prévia de análise pela justiça desportiva da matéria atinente às competições desportivas não fere o princípio do acesso à justiça, mas mitiga-o, tratando-se de uma exceção prevista constitucionalmente, sendo que o legislador constituinte originário procurou uma convivência harmoniosa e simultânea entre princípios norteadores do direito pátrio, assim como garantiu uma análise de matéria específica pela justiça especializada, para com isso não só legitimá-la como instância administrativa, mas também ofertar maior celeridade e efetividade na resolução do contencioso desportivo.

\section{CONSIDERAÇÕES FINAIS}

O presente trabalho teve por finalidade inicial discutir tema afeto ao direito desportivo, contribuindo para a ampliação da compreensão acerca dos limites de atuação da justiça desportiva e, principalmente, da justiça estatal/Poder Judiciário.

A importância da discussão trazida tem por base a relevância do desporto para a sociedade, especialmente quando visto e entendido como atividade de impacto social e de grande porte econômico, com repercussões no âmbito do direito.

O desporto não pode ser considerado apenas como atividade lúdica e de mero deleite. Trata-se, em verdade, de um fenômeno social, com forte repercussão econômica, impactando no mundo jurídico. Por essa razão, o tema merece tratamento específico capaz de observar suas peculiaridades e características próprias, as quais reforçam o reconhecimento de sua autonomia diante de outros ramos da ciência jurídica.

Não é de hoje que se discute no âmbito da justiça comum questões afetas ao direito desportivo. Até onde o togado pode adentrar nas demandas de natureza desportiva é questão tormentosa. Na esfera constitucional, é indiscutível que o princípio da 
inafastabilidade da jurisdição ou do livre acesso à justiça é norma basilar que garante a todos os jurisdicionados o direito de trazer ao Poder Judiciário o exame de qualquer lesão ou ameaça a direito. Nada pode ser excluído da apreciação da justiça estatal.

Contudo, a própria Constituição oferece uma situação de exceção, qual seja, a exigibilidade de que o contencioso desportivo seja previamente exaurido pela justiça desportiva para, somente então, poder-se trazer a discussão para o âmbito da justiça estatal, ocasião em que o mérito administrativo já apreciado pela justiça desportiva não será modificado, fixando-se a análise nas questões de ordem processual ou eventuais nulidades que visem a garantir a efetividade dos princípios constitucionais consagrados, tais como o contraditório e a ampla defesa.

Relembre-se que a justiça desportiva não é órgão pertencente ao poder judiciário, tratando-se de instituição mista com função decisória, cujas decisões possuem natureza administrativa, fazendo coisa julgada apenas no âmbito desportivo, desde que observados os princípios constitucionais e as determinações legais.

Dito isso, a antinomia entre o princípio da inafastabilidade da jurisdição $\left(\mathrm{CF}\right.$, art. $\left.5^{\circ}, \mathrm{XXXV}\right)$ e a exigência de análise prévia do contencioso pela justiça desportiva $\left(\mathrm{CF}\right.$, art. 217, $\left.\S 1^{\circ}\right)$ é apenas aparente. Resta fortalecido o entendimento de que há uma convivência harmônica entre referidos dispositivos constitucionais, uma vez que a exigibilidade prévia de exaurimento do contencioso desportivo pela justiça desportiva para posterior análise pelo Poder Judiciário é considerada uma limitação/exceção ou mitigação/relativização do princípio do livre acesso à justiça, não só porque alçada à norma constitucional pelo próprio poder constituinte originário - princípio da unidade da constituição -, mas também por garantir ao fenômeno do desporto, com status constitucional (CF/88, seção III), a certeza de uma análise por justiça especializada, célere e ágil no trato dos processos relacionados à disciplina e às competições esportivas. Assim, garante-se ao Poder Judiciário o controle da legalidade e dos vícios ou irregularidades formais não observadas pela justiça desportiva.

Pretende-se, talvez de forma muito ousada, que o tema em destaque possa encontrar espaço nas fileiras de discussões jurídicas. Não se quer esgotar ou encerrar o assunto; ao contrário, almeja-se, humildemente, incentivar os operadores do direito, 


\title{
Ranctab

notadamente magistrados, a refletir, discutir e evoluir na ideia de um direito desportivo como ramo autônomo da ciência jurídica, contribuindo para a construção de um cenário desportivo nacional seguro, previsível e justo.

\section{THE REQUIREMENT OF THE EXPANSION OF SPORTS JUSTICE: UNCONSTITUTIONALITY OR MITIGATION OF THE PRINCIPEL OF INAFASTABILITY OF JURISDICTION?}

\author{
Edson Lemos \\ Rafael Maas dos Anjos
}

\begin{abstract}
Does the demand for the exhaustion of sporting justice constitute an affront to the principle of inafastability of jurisdiction? The answer to this questioning is the focus of the present study. In the legal environment, there has long been the filing of lawsuits that have as their object conflicts in the arena of sporting justice. For the knowledge of the conflict in the judicial process and the receipt of possible action necessary to pass the examination of a preliminary question: to verify if the litigation has already exhausted itself in the sports arena or if it has surpassed the legal term for its examination. In this context, as it will be seen, the requirement of exhaustion of a certain quaestio in sports justice is a mitigation of the principle of inafastability of jurisdiction and not its unconstitutionality. In order to reach this conclusion, it will be sought to map the respective constitutional foundations, giving prominence to sports law, in addition to analyzing the right of action, its origin, importance and relation with the principle of access to justice. We will discuss the sports litigation in order to find subsidies capable of clarifying that the provision of article 217, paragraph 1st, of the Federal Constitution, does not violate the command contained in article 5th, XXXV, also of the Magna Carta, both constitutional devices being able to live in harmony.
\end{abstract}

Keywords: Access to justice. Inafastability of jurisdiction. Judiciary. Sports justice. 


\section{REFERÊNCIAS}

ANJOS, Rafael Maas dos. A responsabilidade civil das entidades desportivas por dano ao torcedor. Curitiba: Prisma, 2016.

BOGDAN, Felipe Branco. A Justiça desportiva e o poder judiciário: uma análise à luz do princípio da inafastabilidade do controle jurisdicional. Monografia apresentada ao Curso de Graduação em Direito da Universidade Federal de Santa Catarina, como requisito à obtenção do grau de Bacharel em Direito, 2009. Disponível em:

<http://www.egov.ufsc.br/portal/sites/default/files/anexos/33839-44319-1-PB.pdf >. Acesso em: 14 jun. 2018.

BRASIL. Lei n. 9.615, de 24 de março de 1998. Institui normas gerais sobre desporto e dá outras providências. Diário Oficial da União. Brasília, mar. 1998.

CANOTILHO, José Joaquim Gomes. Direito constitucional. 5 ed. Coimbra-Portugal: Livraria Almedina, 1991.

CAPPELLETTI, Mauro; GARTH, Bryant. Acesso à justiça. Porto Alegre: Sérgio Antonio Fabris, 1988.

CASTRO, Luiz Roberto Martins. A natureza jurídica do direito desportivo. Revista do Instituto Brasileiro de Direito Desportivo, São Paulo, OAB, v. 1, 2002.

DIDIER Jr., Fredie. Curso de direito processual civil [livro eletrônico]: introdução ao direito processual civil, parte geral e processo de conhecimento. 17 ed. Salvador: Jus Podivm, 2015.

DONIZETTI, E. Curso didático de direito processual civil. 18. ed. ver., ampl. e atual. especialmente de acordo com as Leis n. 12.424/2011, 12.431/2011 e 12.810/3013. São Paulo: Atlas, 2014.

EZABELLA, Felipe Legrazie. O direito desportivo e a imagem do atleta. São Paulo: IOB Thomson, 2006.

FERREIRA FILHO, Manuel Gonçalves. Comentários à constituição brasileira de 1988. v. 2: arts. 104 a 250. 2 ed. atualizada e reformulada. São Paulo: Saraiva, 1999. p. 265.

GONÇALVES, Marcus Vinicius Rios. Direito processual civil esquematizado. 6. ed. São Paulo: Saraiva, 2016.

GRISARD, Luiz Antônio. Justiça do trabalho ou justiça desportiva? Jus Navigandi, Teresina, ano 7, n. 56, abr. 2002. Disponível em: <www1.jus.com.

br/doutrina/texto.asp?Id=2826>. Acesso em: 08 jul. 2017. 
GUIMARÃES, Deocleciano Torrieri. Dicionário técnico jurídico. Atualização de Ana Claudia Schwenck dos Santos. 18 ed. São Paulo: Rideel, 2015.

MARINONI, Luiz Guilherme. Novo curso de processo civil [livro eletrônico]: teoria do processo civil. 2. ed. São Paulo: Revista dos Tribunais, 2016.

MELO FILHO, Álvaro. Direito Desportivo: novos rumos. Belo Horizonte: Del Rey, 2004. . Direito desportivo atual. Rio de Janeiro: Forense, 1986.

O desporto na ordem jurídico-constitucional brasileira. São Paulo: Malheiros Editores Ltda., 1995.

Nova Lei Pelé: avanços e impactos. Rio de Janeiro: Maquinária, 2011.

MIRANDA, Martinho Neves. O Direito no desporto. Rio de Janeiro: Lúmen Juris, 2007.

MORAES, Alexandre de. Constituição do Brasil interpretada e legislação constitucional. 2. ed. São Paulo: Atlas, 2003.

NEVES, Daniel Amorim Assumpção. Manual de Direito Processual Civil. 7. ed. rev., ataul. e ampl. São Paulo: Método, 2015. 2016.

Novo código de processo civil comentado artigo por artigo. Salvador: JusPodivm,

PASOLD, Cesar Luiz. Metodologia da pesquisa jurídica: teoria e prática. 12 ed. rev. São Paulo: Conceito Editorial, 2011.

REZENDE, José Ricardo. Nova legislação de direito desportivo: preparando o Brasil para a Copa 2014 e Olimpíadas 2016. São Paulo: All Print, 2010.

SCHMITT, Paulo Marcos. Curso de justiça desportiva. São Paulo: Quartier Latin, 2007. Direito e justiça desportiva. v.1. Ibookstore, 2013. Disponível em:

$<$ https://itunes.apple.com/br/book/direito-justica-desportiva/id634251949?mt=11>. Acesso em 20 jun. 2018.

SILVA, José Afonso da. Curso de direito constitucional positivo. 23. ed. Rev. e atual. São Paulo: Malheiros, 2004.

SPENGLER, Fabiana Marion. Da jurisdição à mediação: por uma outra cultura no tratamento de conflitos. Ijuí: Unijuí, 2010.

VARGAS, Ângelo; LAMARCA, Braz Rafael da Costa. Para uma compreensão do desporto no mundo globalizado: das tramas sociais ao positivismo jurídico. In MACHADO, Rubens 
Revista do

CEJUR/TJSC:

Prestação Jurisdicional

ISSN: 2319-0876

ISSN Eletrônico: 2319-0884

Approbato. et al. Curso de direito desportivo sistêmico. v. 2. São Paulo: Quartier Latin, 2010. p. 21-26. 